\title{
Morphology and ecology of Thalassiosira Cleve (Bacillariophyta) species rarely recorded in Brazilian coastal waters
}

\author{
Garcia, $M .^{\mathrm{a} *}$ and Odebrecht, $C .^{\mathrm{b}}$ \\ aDepartamento de Botânica, Universidade Federal de Pelotas - UFPel, \\ CEP 96010-900, Pelotas, RS, Brazil \\ 'Instituto de Oceanografia, Universidade Federal do Rio Grande - FURG, \\ CEP 96201-900, Rio Grande, RS, Brazil \\ *e-mail: marines@ufpel.edu.br \\ Received June 2, 2008 - Accepted July 28, 2008 - Distributed November 30, 2009
}

(With 67 figures)

\begin{abstract}
The detailed description of rarely recorded Thalassiosira species in Brazil is presented with light microscope (LM) and scanning electron microscope (SEM) illustrations. A total of 78 phytoplankton net samples $(20 \mu \mathrm{m})$ collected between the years 2000 and 2006 in coastal waters of southern Brazilian, Cassino Beach and the estuary of Lagoa dos Patos, were studied in cleaned material using the Axiovert Zeiss LM and Jeol 6060 SEM. Water temperature and salinity of samples and six species are presented: Thalassiosira endoseriata, T. hendeyi, T. lundiana, T. minuscula, T. oceanica and T. wongii. Two species, Thalassiosira hendeyi and T. endoseriata were the most common being observed in all seasons at Cassino Beach in a wide temperature range $\left(10-26^{\circ} \mathrm{C}\right)$, while only sporadically in the estuary of Lagoa dos Patos. Thalassiosira endoseriata, T. lundiana, T. oceanica and T. wongii are for the first time reported in Brazilian coastal waters. The latter two species, rarely recorded in the world, are fully illustrated based on Brazilian material.
\end{abstract}

Keywords: taxonomy, marine diatoms, phytoplankton, ultra-structure.

\section{Morfologia e ecologia de espécies de Thalassiosira Cleve (Bacillariophyta) raramente registradas em águas costeiras brasileiras}

\begin{abstract}
Resumo
A descrição detalhada de seis espécies de Thalassiosira raramente registradas no Brasil é apresentada com ilustrações em microscopia óptica (MO) e microscopia eletrônica de varredura (MEV). Foram estudadas 78 amostras de rede (malha de $20 \mu \mathrm{m}$ ) coletadas entre os anos de 2000 e 2006 em águas costeiras do sul do Brasil, na praia do Cassino e no estuário da Lagoa dos Patos. Dados relativos à temperatura da água e salinidade são apresentados. Thalassiosira endoseriata, T. hendeyi, T. lundiana, T. minuscula, T. oceanica e T. wongii foram estudadas em amostras oxidadas ao MO Axiovert Zeiss e MEV Jeol 6060. Thalassiosira hendeyi e T. endoseriata foram as espécies mais comumente observadas in todas as estações do ano na praia do Cassino em uma grande amplitude de temperatura $\left(10-26{ }^{\circ} \mathrm{C}\right)$, mas foram observadas esporadicamente no estuário da Lagoa dos Patos. Thalassiosira endoseriata, T. lundiana, T. oceanica e T. wongii são, pela primeira vez, registradas em águas costeiras brasileiras. As duas últimas espécies, raramente registradas em águas costeiras em geral, são ilustradas em detalhe com espécimens brasileiros.
\end{abstract}

Palavras-chave: taxonomia, diatomáceas marinhas, fitoplâncton, ultraestrutura.

\section{Introduction}

The morphological identification of Thalassiosira species is mainly based on ultra-structure details like the number and location of the rimoportulae and fultoportulae processes on the valve. Examination of the frustules in the electron microscope (EM) is essential for identification of most species, as recognized since the first transmission and scanning electron microscopy studies of Thalassiosira respectively in the 1950s and 1960s (Helmcke and Krieger, 1953; 1954; Hasle, 1968). EM analysis greatly enhanced taxonomy fundaments and morphological details important for the recognition of Thalassiosira species and the identification of more than 
100 species present in most marine environments (Hasle and Syvertsen, 1996).

On the Brazilian coast, thirty seven marine and brackish water taxa were cited but only five of them, T. oestrupii (Ostenfeld) Cleve, T. nanolineata (Mann) Fryxell and Hasle, T. eccentrica (Ehrenberg) Cleve, T. punctigera (Castracane) Hasle and T. oestrupii var. venrickae Fryxell and Hasle were illustrated in the light microscope (LM). Three studies only include scanning electron microscopy (SEM) microphotographs (Ribeiro, 1996; Torgan and Santos 2006; 2007). The highest number of Thalassiosira species was found in the southern Brazilian shelf and slope waters near the boarder with Uruguay $\left(38^{\circ} 12^{\prime} \mathrm{S}\right.$ and $57^{\circ} 15^{\prime}$ 'W-39 $59^{\prime} \mathrm{S}, 54^{\circ} 11^{\prime} \mathrm{W}$; 22 species, Lange and Mostajo, 1985) and along the coast of Paraná State $\left(25^{\circ} 20^{\prime}-25^{\circ} 55^{\prime} \mathrm{S}\right.$ and $48^{\circ} 10^{\prime} \mathrm{S}-48^{\circ} 35^{\prime} \mathrm{W}$; 24 species, Procopiak et al., 2006).

This study aims to describe and give a full set of illustrations of six Thalassiosira species to date rarely recorded or unrecorded in Brazilian waters. T. oceanica and $T$. wongii, rarely recorded in the world, are fully described and illustrated based on southern Brazilian material. Three stations were analysed between the years 2000 and 2006, and environmental conditions and seasonal species distribution are discussed.

\section{Material and Methods}

Monthly phytoplankton samples were obtained in the framework of the Ecological Long Term Programme at three stations: 1) the surf zone in Cassino Beach in front of the Aquaculture Marine Station (EMA) of the Federal University of Rio Grande, FURG (32 $12^{\circ}$ S and $\left.52^{\circ} 10^{\prime} \mathrm{W}\right), 2$ ) the Lagoa dos Patos estuary in front of the FURG Oceanographic Museum ( $32^{\circ} 01^{\prime} \mathrm{S}$ and $52^{\circ} 06^{\prime} \mathrm{W}$ ), and 3 ) the estuary main channel at the mouth of Lagoa dos Patos ( $32^{\circ} 09^{\prime} \mathrm{S}$ and $52^{\circ} 06^{\prime} \mathrm{W}$ ). Phytoplankton was collected with a conical net $(20 \mu \mathrm{m}$ mesh aperture), preserved with $4 \%$ buffered formaldehyde and kept in glass flasks (200 mL). The environmental characteristics, temperature and salinity were measured with a mercury thermometer and Yellow Spring Conductivity meter.

A total of 78 net samples collected between the years 2000 and 2006 were cleaned using the method presented by Simonsen (1974). To produce permanent slides, aliquots of clean material were dried on cover slips and mounted on glass slides, using Hyrax. Morphological analysis and measurements were performed using the Zeiss Axiovert 135 optical microscope equipped with Nomarski interference contrast, and the scanning electron microscopy (SEM). For SEM, cleaned valves and frustules were dried on $16 \mathrm{~mm}$ diameter cover slip previously fixed on an aluminum stub, coated with gold at $1 \mathrm{kV}$ for 4 minutes, and examined with JEOL JSM6060 at an accelerating voltage of $15-20 \mathrm{kV}$. The working distance was $10 \mathrm{~mm}$. The number of the marginal fultoporutlae in $10 \mu \mathrm{m}$ was calculated as $\mathrm{n} \times 10 \div \pi \mathrm{d}$, where $\mathrm{d}$ is the valve diameter as measured on the LM or SEM picture, and $\mathrm{n}$ the number of fultoportulae of a particular valve (Hasle, 1983).

\section{Species Studied and Remarks}

3.1. Thalassiosira endoseriata Hasle and Fryxell,

Nova Hedwigia Beiheft 54: 78-79, figs 45-49. 1977.

Figures 1-2 and 14-22

References: Mahood et al. (1986), Fryxell and Hasle (1977).

Dimensions: diameter: $30-58 \mu \mathrm{m}$; areolae in $10 \mu \mathrm{m}$ : 10-11; number of fultoportulae in the central ring: 7-13; marginal fultoportula in $10 \mu \mathrm{m}$ : 5-6.

Remarks: The measurements are in agreement with the original description. It is rarely recorded in the literature. According to Sar et al. (2001) it is more common in winter in Argentinean waters. Mahood et al. (1986) observed few specimens in S. Francisco Bay. Cited also in coastal areas from Africa and Chile $\left(03^{\circ} 05^{\prime}-54^{\circ} 14^{\prime} \mathrm{S}\right)$ Fryxell and Hasle (1977).

3.2. Thalassiosira hendeyi Hasle and Fryxell, Nova Hedwigia Beiheft 54: 25, figs. 35-45. 1977.

Figures 3-5 and 23-31

References: Aké-Castillo et al. (1999), Hasle and Fryxell (1977), Mahood et al. (1986), Sar et al. (2001).

Dimensions: diameter: 49-79 $\mu \mathrm{m}$; mantle ribs in number of 7-8 in $10 \mu \mathrm{m}$; striae density: 5-6 in $10 \mu \mathrm{m}$.

Remarks: The number of satellite pores around the fultoportulae is not mentioned in the original description. Mahood et al. (1986) shows the marginal fultoportulae with 4 satellite pores and we found in our specimens 4-5 satellite pores around the fultoportulae. According to Hasle and Fryxell (1977), the type material of this species is from Uruguay, found from West Africa to Brazil. Aké-Castillo et al. (1999) observed the species in the dry season in Mexico and considered it tropical, previously recorded in subtropical areas only. The species was considered polyhaline in an estuary (Muylaert and Sabbe 1996) although one valve only was found. According to Sar et al. (2001) it is present from warm to temperate waters in Argentina where it is common all year round, fairly abundant in summer and fall.

\subsection{Thalassiosira lundiana Fryxell, Nova Hedwigia} Beiheft 53: 64-65, figs 12-24. 1975.

Figures 6-7 and 32-38

Reference: Fryxell (1975).

Dimensions: diameter: 21-26.5 $\mu \mathrm{m}$; $12-14$ occluded processes around the valve margin, fultoportulae around the margin: 7-8 in $10 \mu \mathrm{m}$.

Remarks: The material studied has shown a higher number of occluded processes than the maximum recorded by Fryxell (12). Thalassiosira lundiana is rarely recorded in the literature. In the study area, it was more frequently recorded in the warm period (December to March) with temperature $15-29^{\circ} \mathrm{C}$. Sar et al. (2001) also 

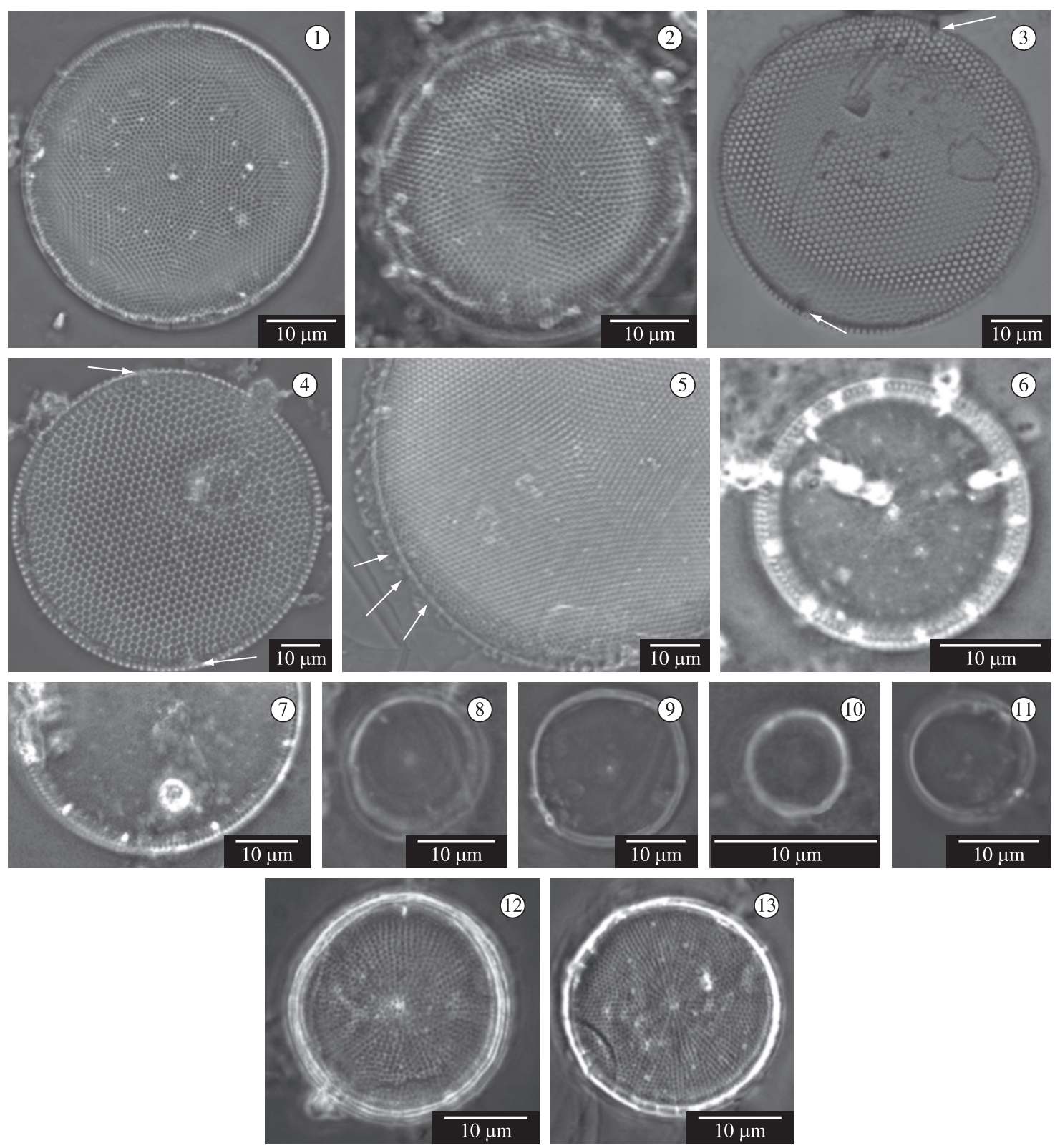

Figures 1-13. Light microscope pictures. Figures 1-2) T. endoseriata; Figures. 3-5) T. hendeyi; Figures 3, 4) The rimoportulae locations are indicated by arrows. Figure 5) Note the marginal ridge (arrowed); Figures 6-7) T. lundiana; Figures 8-9) T. minuscula; Figures 10-11) T. oceanica; Figures 12-13) T. wongii.

found it in summer in Argentinean coastal waters. In San Francisco Bay, it was present in a broad range of salinity (Mahood et al. 1986). In our samples the salinity values ranged between 9 and 36 .

\subsection{T. minuscula Krasske, Archiv für}

Hydrobiologie 38: 262, pl.5, figs 4-6. 1941.

Synonym: Thalassiosira monoporocyclus Hasle, Norwegian Journal of Botany 19: 129, figs. 46-60. 1972.

Figures 8-9 and 29-37
References: Hasle (1972), Hasle (1976), Hallegraeff (1984), Mahood et al. (1986), Hernandez-Becerril and Tapia Peña (1995), Sar et al. (2001).

Dimensions: diameter: $13.6-26 \mu \mathrm{m}$; fultoportulae in $10 \mu \mathrm{m}: 3-4$.

Remarks: The morphological variation of T. minuscula is wider than described by Hasle (1972). The original diagnosis recorded only one fultoportula next to the rimoportula but Hernandez-Becerril and Tapia Peña (1995) and also Sar et al. (2001) recorded the presence of 

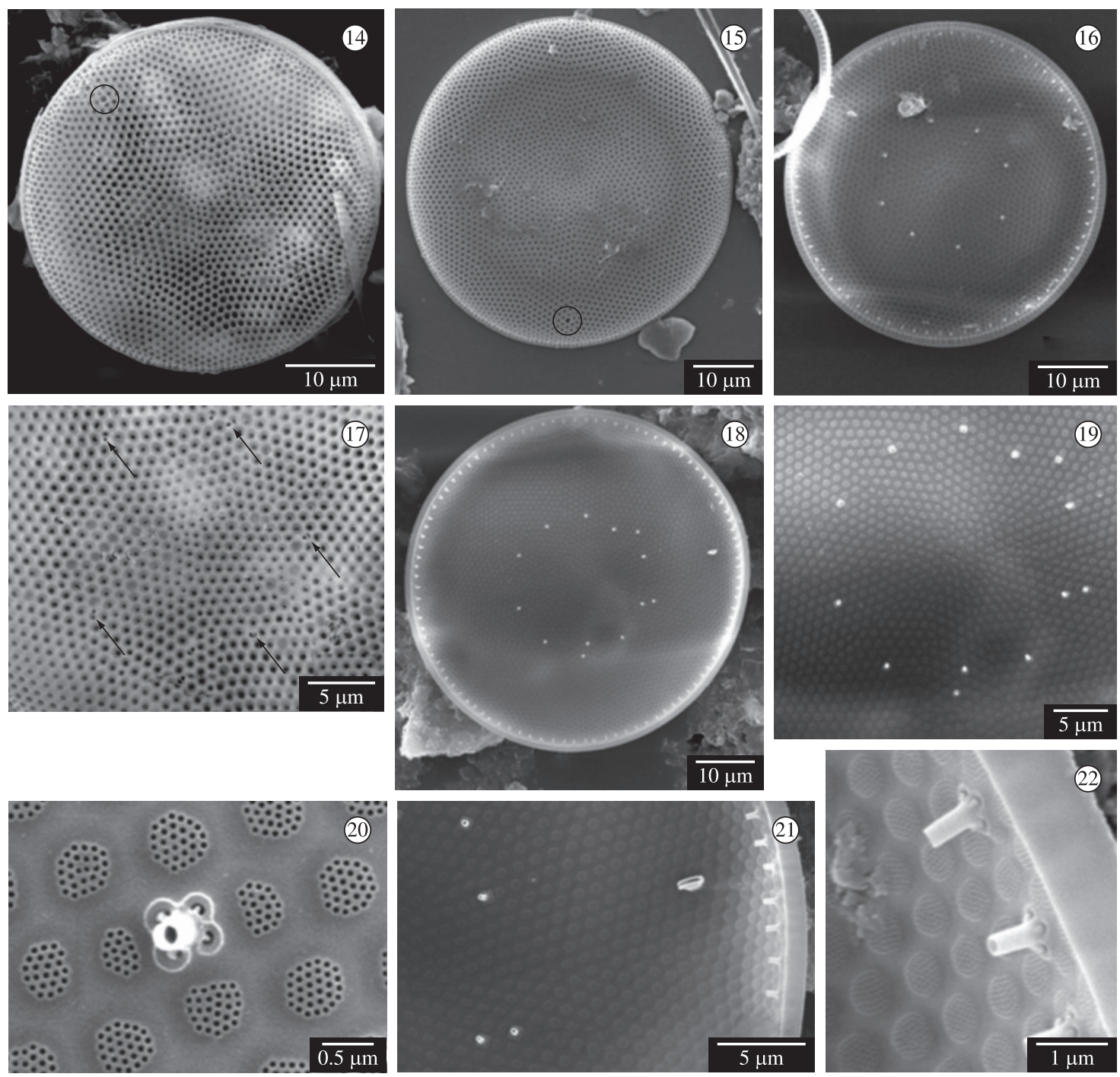

Figures 14-22. T. endoseriata in SEM. Figure 14) External general view of a valve. The rimoportula is in the circle. Figure 15) Another external general view. Also, the rimoportula is in the circle. Figure 16. Internal general view. Note the ring with 8 ultoportulae. Figure 17) Detail of the Figure 14. The arrows indicate the external aperture of the fultoportulae. Figure 18) Internal general view. Figure 19) Detail of figure 18 showing the valve face ring with 13 fultoportulae. Figure 20) Detail of the ring of fultoportulae on the valve face with 4 satellite pores. Figure 21) Detail of the Figure 18 showing part of the ring of fultoportulae on the valve face and the rimoportula close to the valve face edge. Figure 22) Detail of the marginal ring of fultoportulae on the mantle in internal view. The fultoportulae present a short internal tube and 4 satellite pores.

two fultoportula next to the rimoportula. No external tubes from rimoportula or fultoportula were described, although the same authors cited the presence of external tube of the rimoportula. Furthermore, the number of satellite pores is not mentioned in the original description. Mahood et al. (1986) illustrated four satellite pores around the fultoportulae around the marginal ring and we observed 4 to 5 .

T. monoporocyclus was recorded in the Atlantic and Pacific Oceans, off Portugal and Peru (Hasle, 1972). Temperature and salinity in Portuguese samples ranged between 13 and $17.7^{\circ} \mathrm{C}$ and $35.5-36.2$, respectively, and in the Peruvian samples between 15.5 and $17.8^{\circ} \mathrm{C}$ and 34.9 , respectively. In Chile, it was present in summer and fall (December, February, March and April), between $18^{\circ} 20^{\prime}$ and $43^{\circ} 09^{\prime} \mathrm{S}$ (Rivera, 1981). Mahood et al. (1986) recorded it as rare in the central San Francisco Bay. In Argentina, Sar et al. (2001) recorded it as a rare species in summer, fall and winter.

The rare occurrence of this taxon in our samples may be related to the fragility of the valve wall and/or its dissolution in the liquid-preserved samples. 

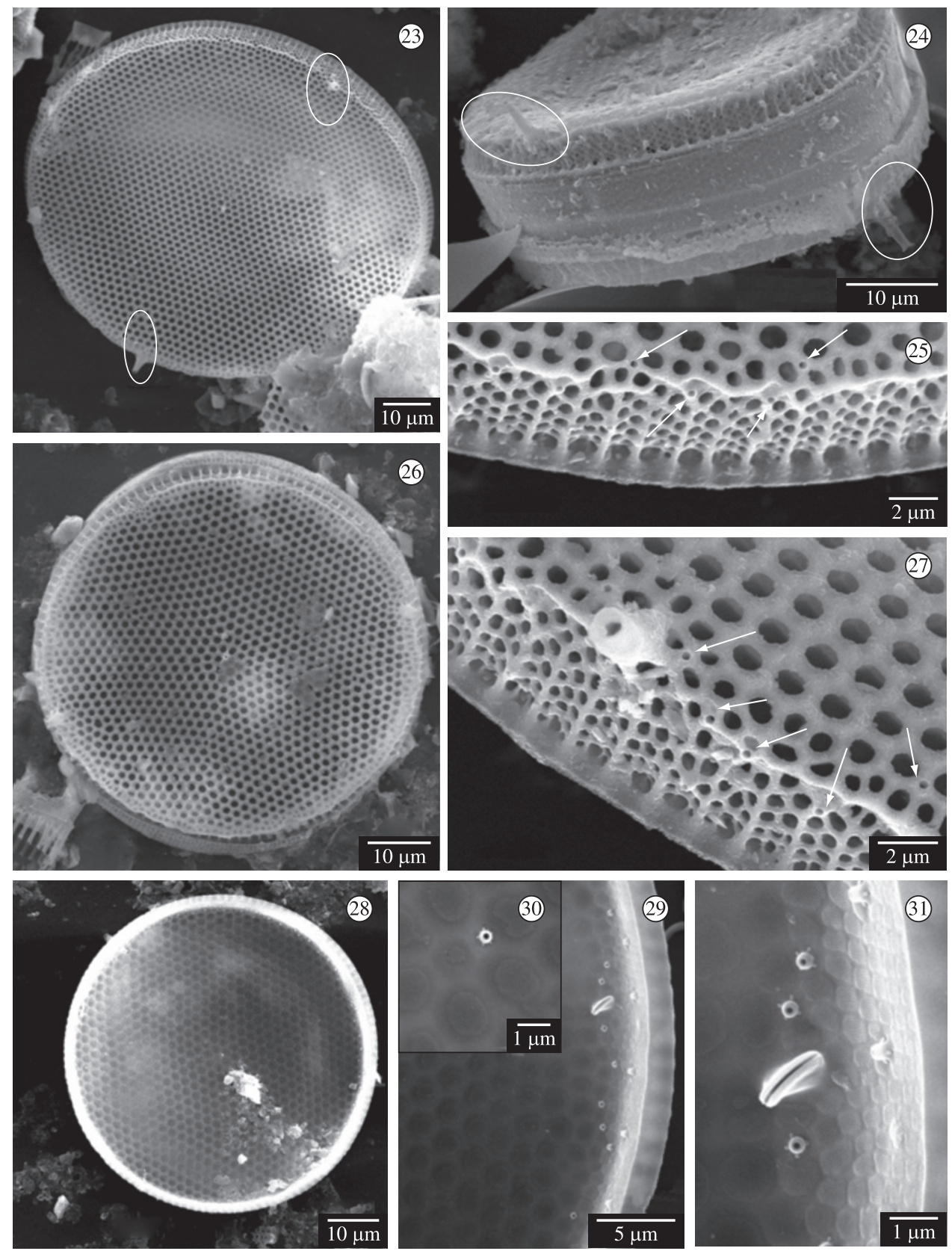

Figures 23-31. T. hendeyi in SEM. Figure 23) External general view of a valve showing the two rimoportulae $180^{\circ}$ apart (both encircled). Figure 24) Frustule in external view showing the position of the rimoportulae in two valves (encircled). Figure 25) Detail of fultoportulae (arrowed) on the valve face marginal ridge and on the mantle. Figure 26) External general view of another valve. Figure 27) Detail of the external tube of the rimoportulae, showing fultoportulae on the valve face, on the marginal ridge and on the mantle. Figure 28) Internal general view of a valve. Figure 29) Detail of the internal aperture of the rimoportulae and fultoportulae from the marginal rings. Figure 30) Detail of the central fultoportula with 5 satellite pores. Figure 31) Detail of Figure 29.

3.5. Thalassiosira oceanica Hasle, Journal of Phycology 19: 220, figs 1-18. 1983.

Figures 10-11 and 48-53

References: Hasle (1983), Hallegraeff (1984), Harris et al. (1995), Herzig and Fryxell (1986).
Dimensions: $4.5-12 \mu \mathrm{m}$ diameter; fultoportulae in $10 \mu \mathrm{m} 3-5$.

The wall structure is very fine and hardly observable in LM (Figures 10-11). The valve face is flat and the mantle is shallow. One prominent and operculate 

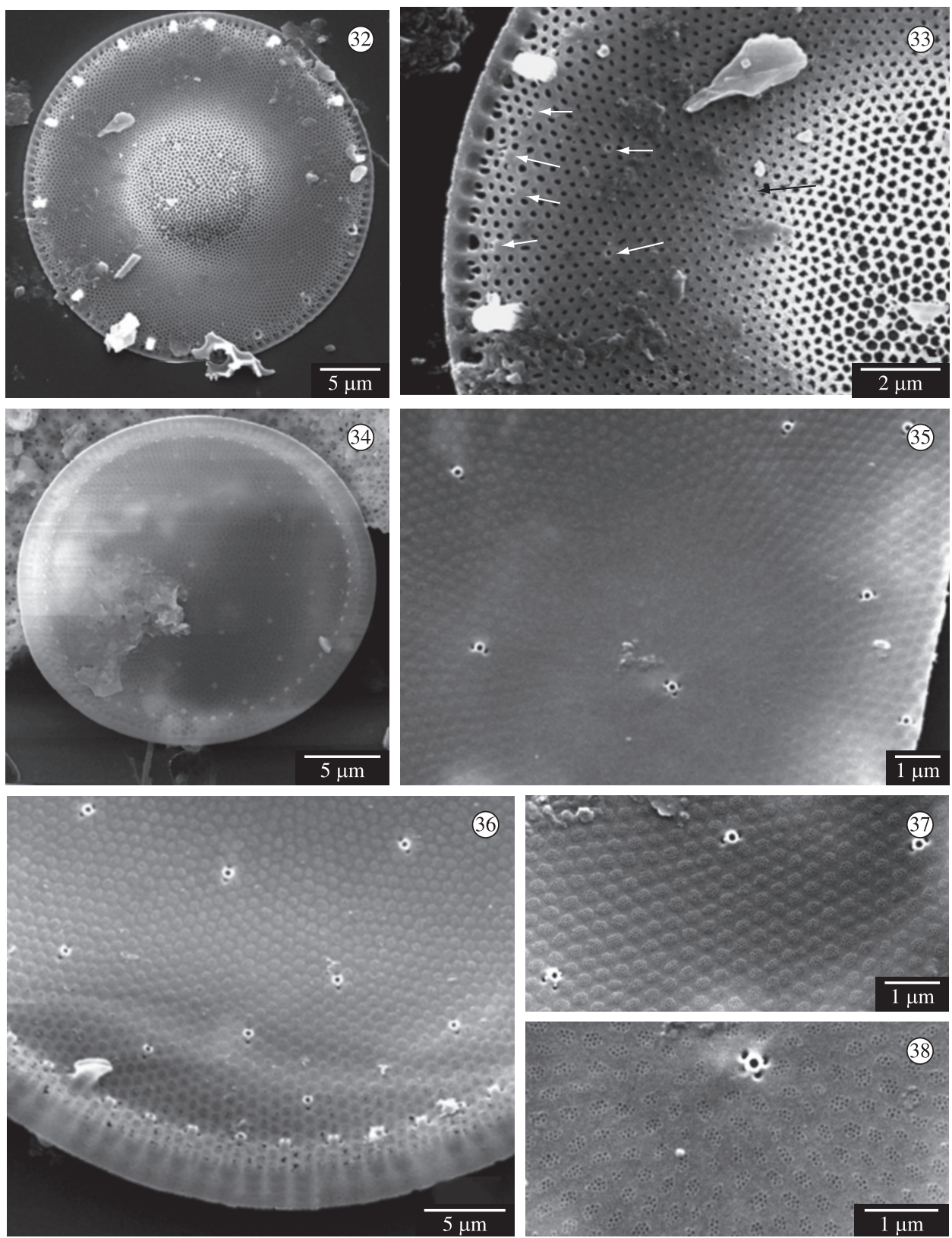

Figures 32-38. T. lundiana in SEM. Figure 32) External view of a valve. Note the presence of several occluded processes around the valve. Figure 33) Detail of Figure 32. The rings of fultoportulae are indicated by arrows. Note the presence of two occluded processes. Figure 34) A general internal view of a valve. Figure 35) Detail of an internal view of valve showing the presence of fultoportulae with two or three satellite pores. Figure 36) A partial internal view of a valve. Note the presence of the rimoportulae and more than two loose rings of fultoportulae. Figure 37) Detail of fultoportulae with two or three satellite pores. Figure 38) Detail of the central fultoportulae with three satellite pores.

fultoportula is close to the centre (Figure 53). The striae are very fine and radiate from the central rimoportula (Figures 49-52). They become coarser next to the margin. Around the valve face edge, one ring of fultoportulae is present (Figures 49-52). Each fultoportula presents a ribbed and operculate external and short tube (Figures 48-51). The rimoportula is next to one fultoportula and both are located at the same level of the fultopotulae marginal ring (Figures 48-51). The valvocopula is ornamented by several rows of poroids (Figure 52). The poroids in the advalvar row are coarser and regularly arranged. 

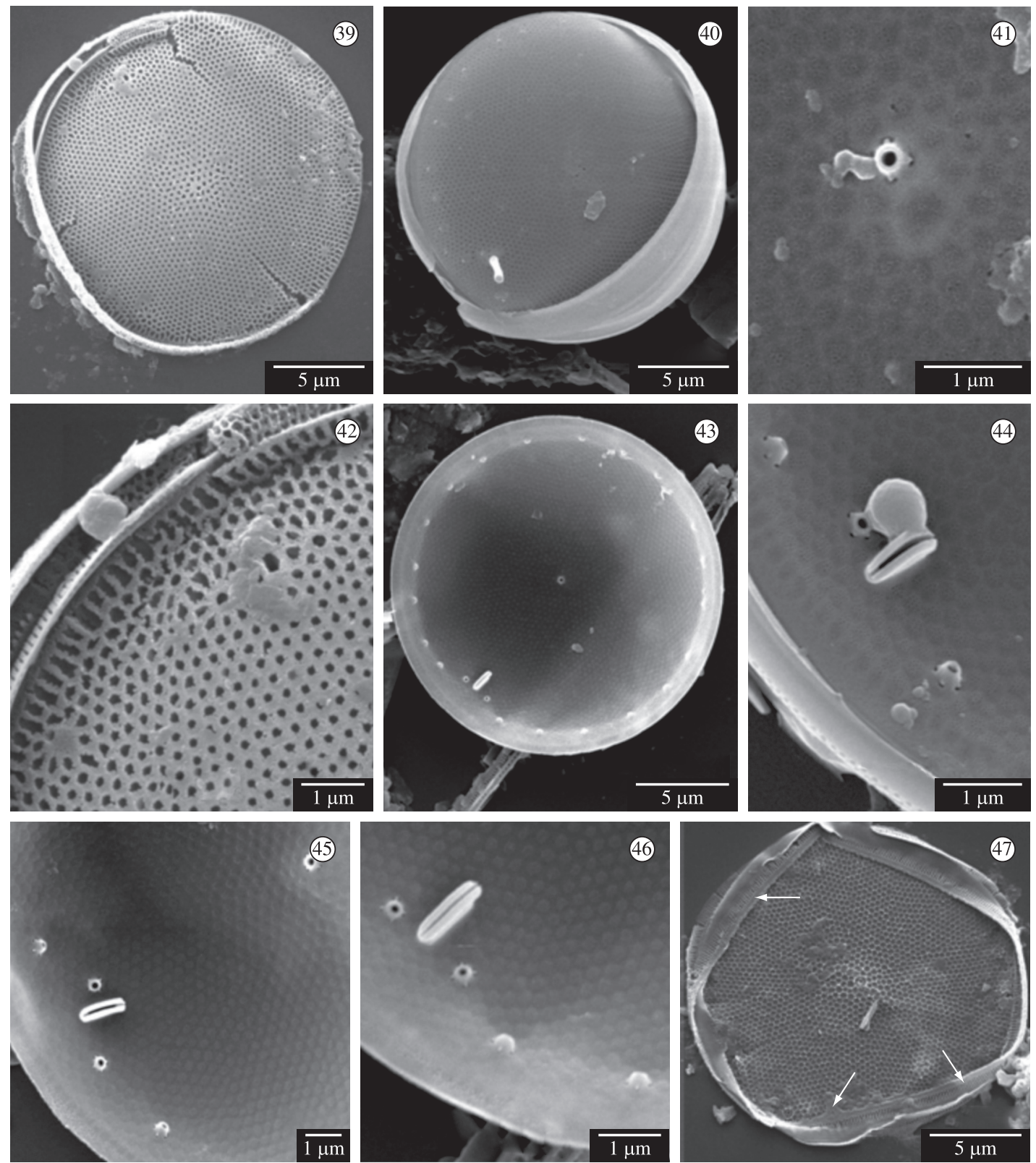

Figures 39-47. T. minuscula in SEM. Figure 39) External general view of a valve. Note the fasciculated striae. Figure 40) External general view of a valve with rimoportula external tube. Figure 41) Internal view of the central fultoportula with 4 satellite pores. Figure 42) Detail of Figure 39 showing external details of areolae around the fultoportulae. Note two fultoportulae next to the rimoportula slightly inwards from the marginal ring of fultoportula. Figure 43) Internal general view of a valve showing the rimoportula next two fultoportulae. Figure 44) Internal view of a rimoportula next to one fultoportula. Note the marginal fultoportulae with four satellite pores. Figure 45) Detail of an internal view of a valve. Figure 46) Detail of Figure 43. Figure 47) External view of valve with the bands collapsed. Note the ligula and the elongated pores (arrowed).

Remarks: Thalassiosira oceanica is recorded in warm and cold waters. It occurs in the spring season in Mexico (Duran, 1992) and Kaczmarska et al. (2005) cited it as a warm water species, strains being cultivated at $20^{\circ} \mathrm{C}$. On the other hand, Harris et al. (1995) found it in Scotland $\left(56^{\circ} 32^{\prime} \mathrm{N}\right)$ and Hasle (1983) maintained the cultures at $12{ }^{\circ} \mathrm{C}$. It seems this species thrives during warm periods. Regarding its habitat, according to Hasle (1983) it is a marine mainly oceanic species while Hallegraeff (1984) observed it inshore and offshore 

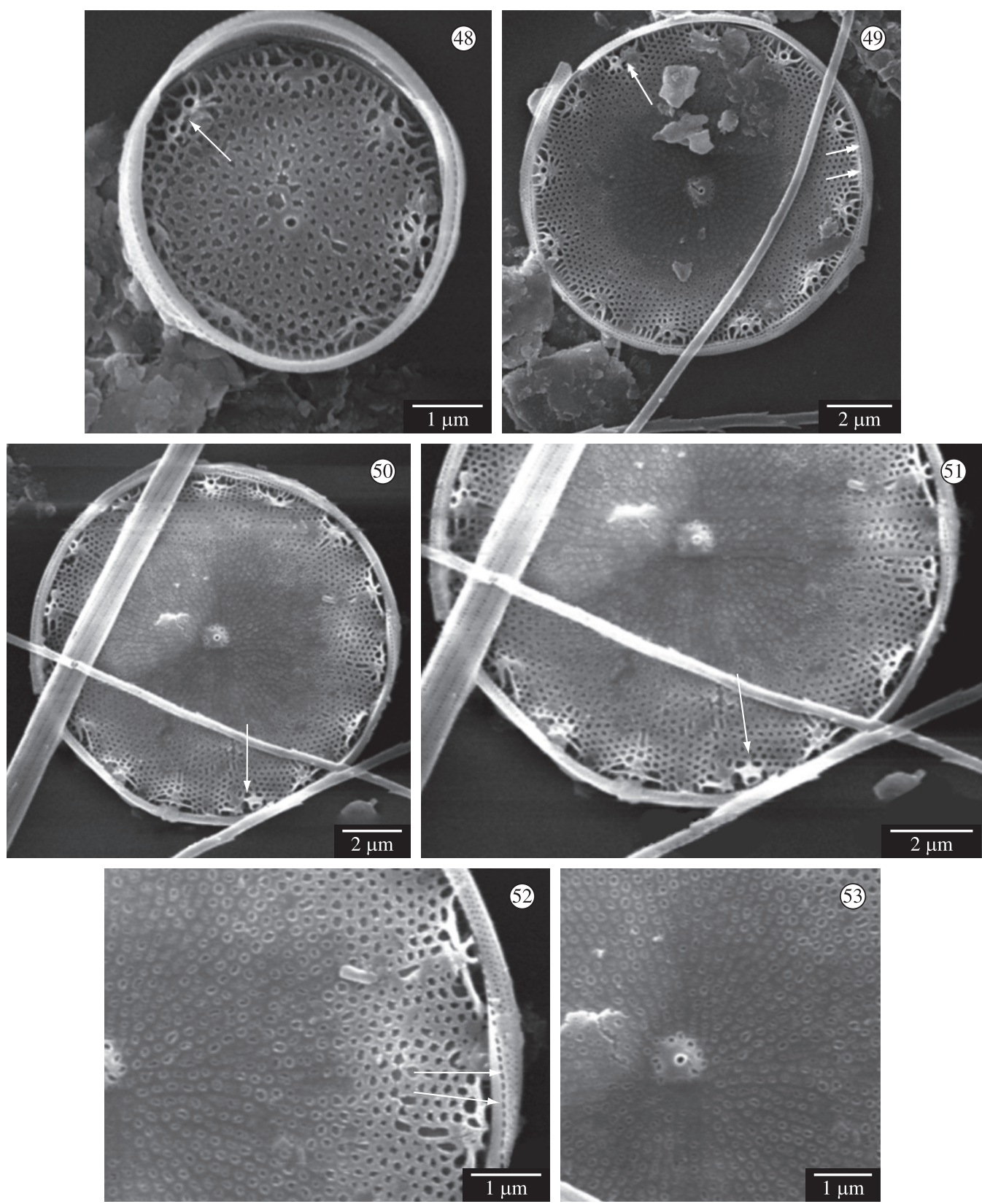

Figures 48-53. T. oceanica in SEM. Figure 48) External view of a small cell. Note the rimoportula located in the ring of fultoportulae (arrowed). Figure 49) External view of another cell. The rimoportula next to a fultoportula is arrowed. Note the valvocopula with pores (arrowed). Figure 50) External view of a cell. The rimoportula is arrowed. Figure 51) Detail of Figure 50. The rimoportula is arrowed. Figure 52) Detail the marginal ring of fultoportulae and the valvocopula with advalvar row of coarse poroids (arrowed). Figure 53) Detail of the operculate fultoportula located next to the center.

Australia $\left(34^{\circ} 05^{\prime} \mathrm{S}\right)$. There is no record of the species in Uruguay, Argentina and Brazil. It is a new record for the South Atlantic Ocean.

Hasle (1983) described the presence or absence of spines on the valve. The specimens studied here did not present spines and showed a higher number of fultoportulae in $10 \mu \mathrm{m}$ (5) compared to the maximum recorded by Hasle (1983) of 4 fultoportulae in $10 \mu \mathrm{m}$. Other characteristics are in agreement with the description of Hasle (1983). 
3.6. Thalassiosira wongii Mahood, Proceedings of the California Academy of Sciences 44: 132, figs 24-29, 99-101. 1986.

Figures 12-13 and 54-67

References: Mahood et al. (1986)
Dimensions: diameter: 21.7-30.8 $\mu \mathrm{m}$; areolae in $10 \mu \mathrm{m}: 8-16$; number of fultoportulae in the marginal ring 3-4 $10 \mu \mathrm{m}$; number of marginal spines 4-6 in $10 \mu \mathrm{m}$.

The valve face is flat (Figures 12-13). The areolae are radiate to fasciculate (Figures 12-13). The fultopor-
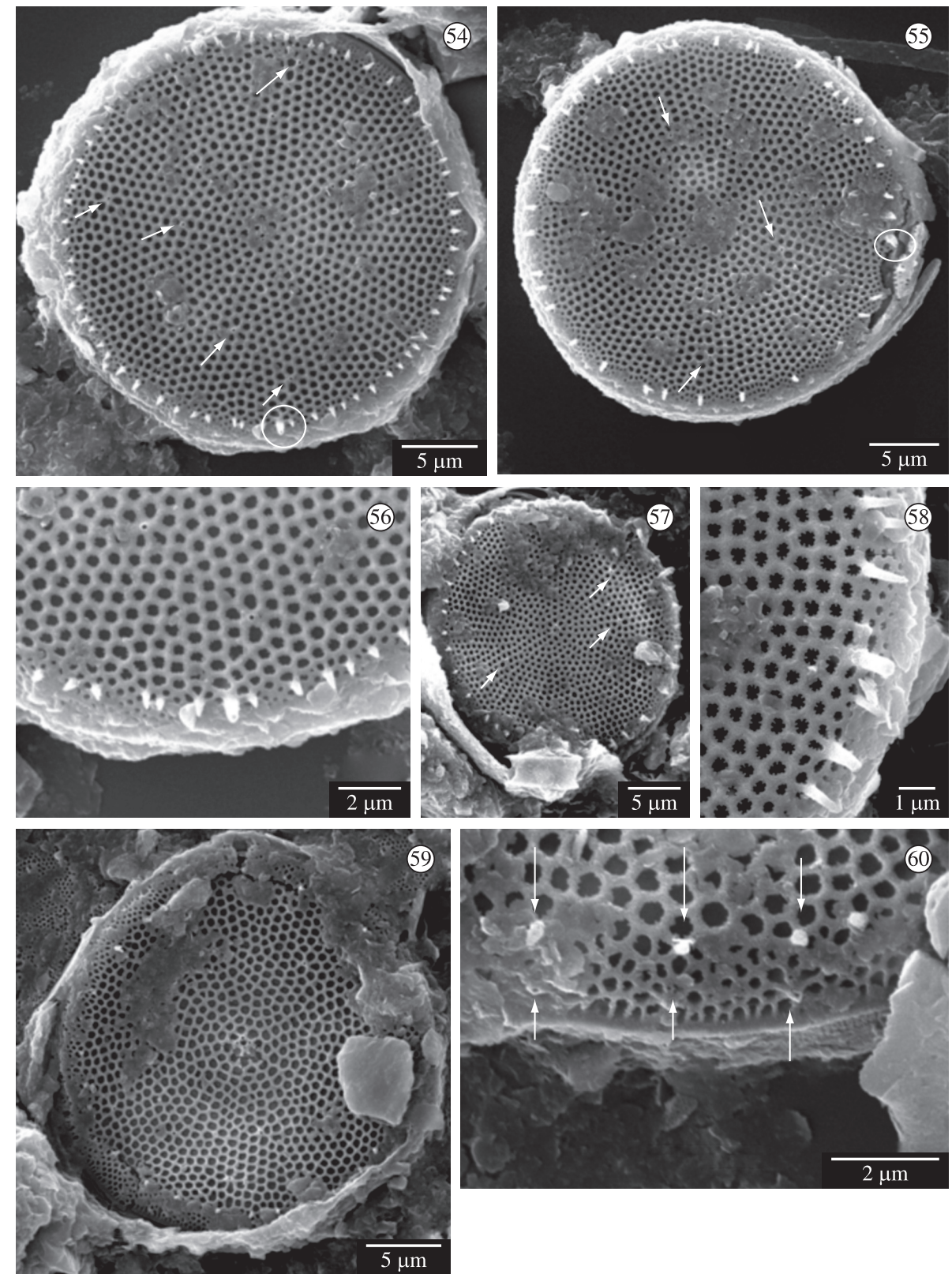

Figures 54-67. T. wongii in SEM. Figure 54) External general view of a valve. The ring of fultoportulae are indicated by arrows. The rimoportula is in the circle. Figure 55) External general view of a valve. The ring of fultoportulae are indicated by arrows. The rimoportula is in the circle. Figure 56) External view. Detail of the valve face edge and rimoportula. Figure 57) Another external general view of a valve. Figure 58) External view. Detail of the valve face edge and rimoportula. Figure 59) Note the presence of four fultoportulae around the central areola. Figure 60) Note the position of spines and fultoportulae (both arrowed) on the valve face edge and mantle. 
tulae form a marginal ring (Figures 54, 55). Around the central areolae there are 4-6 fultoportulae. Each of these central fultoportulae has 3-4 satellite pores (Figure 66). On the valve face there are $2-3$, eventually 4 irregular rings of fultoportulae (Figure 62), each with 4-5 sat- ellite pores (Figure 67). On the edge of the valve face margin there is a ring of short spines (Figures 54-56, $61,63)$. One rimoportula is next to the valve margin (Figure 12). The rimoportula is oriented parallel to the striae (Figures 62, 64). It is interesting to notice that
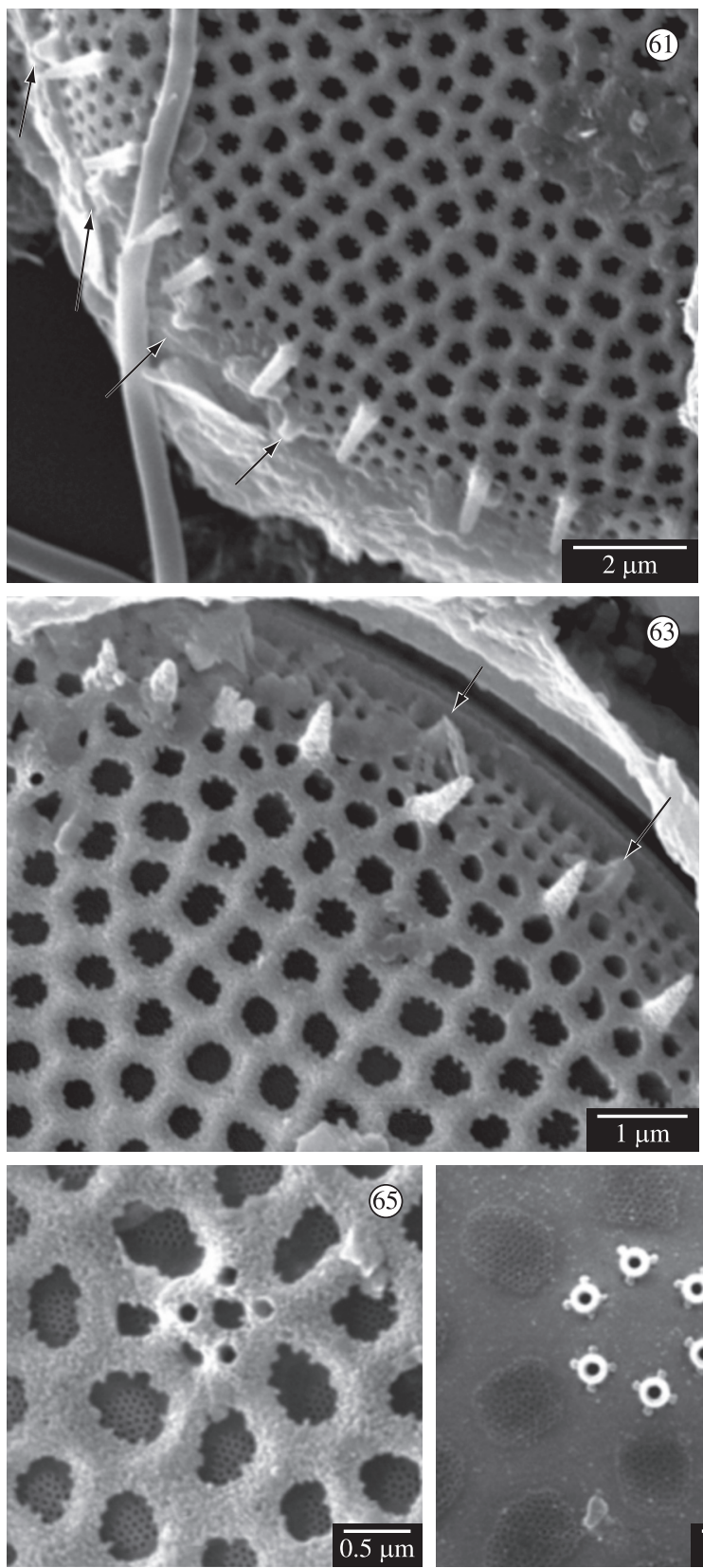
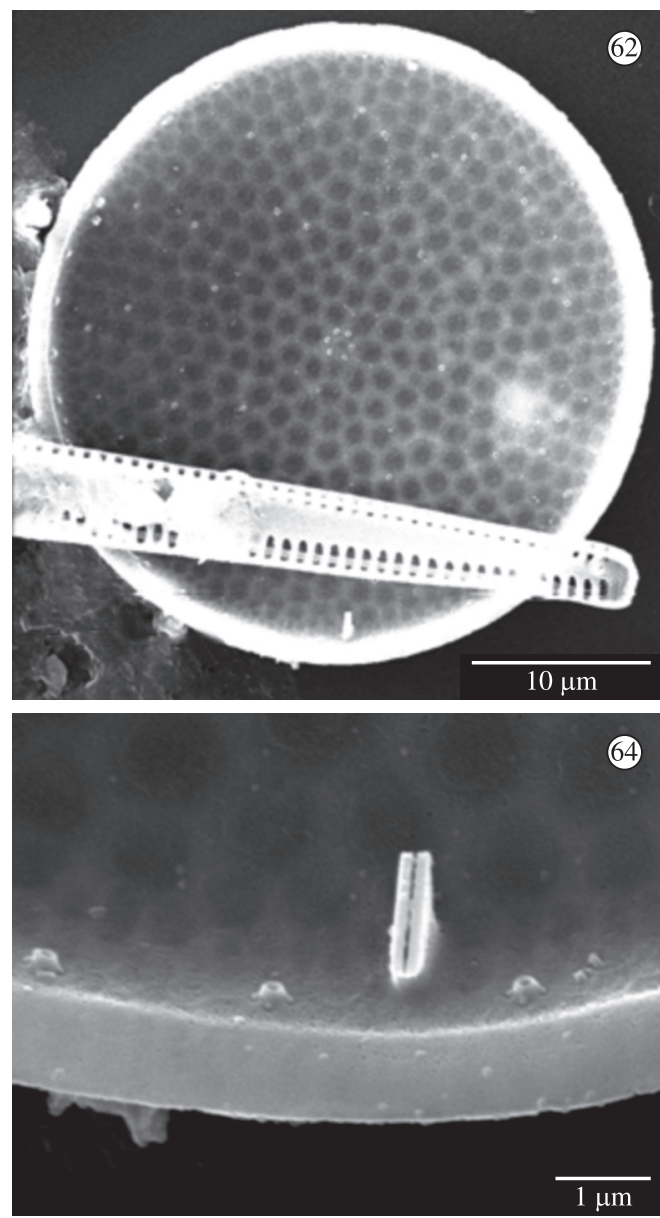

66

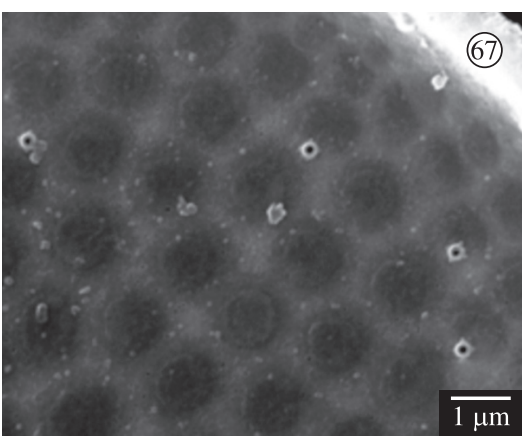

Figures 61-67. Detail of the edge between valve face and mantle in external view. Note the position of spines and fultoportulae on the valve face edge and mantle. The fultoportulae are arrowed. Figure 62) Internal general view of a valve showing rings of fultoportulae on the valve face and the six fultoportulae around the central areolae. Figure 63) Detail of the edge between valve face and mante in external view. Note the spines and fultoportulae (fultoportulae are arrowed). The Figure 64) Internal detail of the rimoportula and fultoportulae with four satellite pores. Figure 65) External view of a valve at the centre. Detail of the central areolae with five fultoportuale and areolae details. Figure 66) Internal view of a valve at the centre. Detail of the fultoportulae with three to four satellite pores. Figure 67) Detail of a valve in internal view showing fultoportulae from the rings located on the valve face close to the margin with four satellite pores. 
Table 1. Sampling station (CAS = Cassino Beach; EST = Lagoa dos Patos estuary; $\mathrm{CH}=$ Lagoa dos Patos main channel), number of studied cells, season $(\mathrm{Su}=$ summer; $\mathrm{F}=$ fall; $\mathrm{Sp}=$ spring), the range of environmental properties and mean values in parenthesis. Salinity: values $<10$ are included separately; mean salinity first number considers all data and second number excludes values $<10$

\begin{tabular}{lcccccc}
\hline & T. endoseriata & T. hendeyi & T. lundiana & T. minuscula & T. oceanica & T. wongii \\
\hline Station and & CAS $=13$ & CAS $=27$ & CAS $=5$ & CAS $=4$ & CAS $=3$ & CAS $=3$ \\
number of & EST $=3$ & EST $=1$ & EST $=1$ & EST $=1$ & EST $=1$ & EST $=3$ \\
occurrences & & & $\mathrm{CH}=2$ & $\mathrm{CH}=1$ & $\mathrm{CH}=2$ & \\
Season & All seasons & All seasons & $\mathrm{Sp}, \mathrm{Su}, \mathrm{F}$ & $\mathrm{Sp}, \mathrm{Su}$ & $\mathrm{Sp}, \mathrm{Su}$ & $\mathrm{Sp}, \mathrm{F}$ \\
Water Temp. & $10-26$ & $10-26$ & $15-29$ & $14-25$ & $17-26$ & $17-26$ \\
$\left({ }^{\circ} \mathrm{C}\right)$ & $(20)$ & $(19)$ & $(23)$ & $(21)$ & $(22)$ & $(20)$ \\
Salinity & $(9) 13-33$ & $(10) 20-36$ & $(9) 25-36$ & $(8 ; 9) 20-36$ & $(8 ; 9) 20-36$ & $(1.8) 20-32$ \\
& $(26 / 27)$ & $(27 / 28)$ & $(28 / 30)$ & $(21 / 27)$ & $(22 / 29)$ & $(20 / 27)$ \\
\hline
\end{tabular}

round patches of dirt were observed on several of the valve faces and seems to be related to the fultoportulae position and mucilage secretion (Figures 54, 55).

Remarks: This is the first report of this species since the original description, and details on satellite pores shown here were not previously illustrated. Slight differences amplify the original diagnosis and the description of a new species seems to be unnecessary. The differences recorded in the Brazilian specimens compared to the original description are: 1) a smaller diameter of the specimens studied than the original description, with a minimum diameter of $27 \mu \mathrm{m}$; 2) the number of fultoportulae 4-6) around the central areola is higher than the original description, with the maximum number of five; 3 ) the number of rings of fultoportulae on the valve face observed in the U.S.A. material was 3 and in the specimens studied they can eventually reach four. Regarding the ecology and distribution of T. wongii, Mahood et al. (1986) comment that this species was found associated to marine species. In the samples studied, T. wongii was observed in sites with low salinity and we suspect this species can also thrive in the Lagoa dos Patos estuary.

\section{Environmental Information}

Of the six studied Thalassiosira species, the most commonly observed were $T$. hendeyi and $T$. endoseriata in all seasons at Cassino Beach, and sporadically in the estuary of Lagoa dos Patos (Table 1). The other species, found in two or all three sampling stations, were not observed in winter samples. The temperature range of $T$. hendeyi and T. endoseriata was slightly wider than that of the other species, as they were also observed in winter samples $\left(10{ }^{\circ} \mathrm{C}\right)$. T. lundiana was observed in the highest temperature $\left(29^{\circ} \mathrm{C}\right)$. The salinity range for all species was large as they were found at least once in the Lagoa dos Patos estuary, but T. wongii was the only one observed in oligohaline water (salinity 1.8). T. hendeyi, T. lundiana, T. minuscula and T. oceanica were observed in highest salinity (36).

\section{Discussion}

Of the six Thalassiosira species, only T. hendeyi and T. minuscula were previously reported in the southern- most Brazilian shelf slope, on the Uruguayan border (Lange and Mostajo, 1985). T. hendeyi was also reported in northern Brazil (Franco, 1991), and Ribeiro (1996) recorded $T$. cf. minuscula as a frequent species in the subtropical Brazilian shelf $\left(16^{\circ}-26^{\circ} \mathrm{S}\right)$. Considering the first report for T. endoseriata, T. lundiana, T. oceanica and $T$. wongii in the present study, the total number of Thalassiosira species for the Brazilian waters would reach forty one. This number is probably overestimated since LM was the principal tool for the identification in most studies. LM is known to be unreliable for the identification of Thalassiosira species, because ultrastructure details cannot be observed. Future studies should be carried out to confirm the real number and identification of Thalassiosira species present in Brazilian waters.

In regional flora studies around the world which include Thalassiosira species (EM identification) the maximum number of species is 25 , as for example from the Southern Hemisphere in Argentina (Sar et al., 2001; 2002, including 20 and 18 species, respectively), Chile (Rivera, 1981; 24 species), Australia (Hallegraeff, 1984; 25 species) and south of the Antarctic Convergence Zone (Johansen and Fryxell, 1985; 20 species). In the Northern Hemisphere, regional floras from Holland (Muylaert and Sabbe, 1996; 13 species), Mexico (Hernandez-Becerril and Tapia Peña, 1995; 18 species; Aké-Castillo et al., 1999; 23 species), San Francisco Bay (Mahood et al., 1986; 20 species) and Scotland (Harris et al. 1995; 17 species) and the number of Thalassiosira species is in the same range.

From the six Thalassiosira species present in southern Brazil, T. wongii is the least studied species, observed in the San Francisco Bay only, its original description location. T. lundiana is poorly recorded, however it was previously observed in Argentinean coastal waters (Sar et al., 2001). T. endoseriata, T. hendeyi and T. minuscula show a worldwide distribution and were also documented in the Southwest Atlantic Ocean, the latter being illustrated as T. cf. minuscula in Brazilian shelf water (Ribeiro, 1996).

San Francisco Bay in the northern Pacific Ocean presents five of the six Thalassiosira species we found in 
southern Brazilian coastal waters, followed by the neighbouring offshore Buenos Aires Province, in Argentine, with four species. The two most frequent species in our study, T. endoseriata and T. hendeyi, were present in a large water temperature range $\left(10-26{ }^{\circ} \mathrm{C}\right)$, as both were found in winter samples. Our data confirm the classification of the latter as a warm to temperate species, but the classification of the former as a warm water species (Hasle and Syvertsen, 1996) is not supported. T. lundiana was the one present in warm water $\left(15-29^{\circ} \mathrm{C}\right)$.

$T$. hendeyi was the most frequent species in our study in all seasons at Cassino Beach (salinity 20-36) and once in the Lagoa dos Patos estuary (June 2003, salinity 10). The frustule of this species presents heavy silica deposition and robust constitution and it rarely would have been missed if present more frequently in samples from Lagoa dos Patos. Thus, we may consider that this species did not tolerate low salinity in the Patos Lagoon estuary, as the other less frequent species did. The higher frequency of $T$. hendeyi in our samples may be related with the frustule characteristics enabling better preservation and tolerance to the cleaning procedure. T. minuscula, T. oceanica and $T$ wongii were all observed on 6 occasions, but T. minuscula was by far the most frequent of them in the samples.

Acknowledgements - The presented study was conducted with financial support from the Brazilian National Scientific and Technological Council-CNPq through the Long Term Ecological Programme PELD-FURG, the CNPq-Taxonomy programme and $\mathrm{CNPq}$ research fellowships to M. Garcia (process n. 155675/2006-0) and C. Odebrecht. The authors thank the Electron Microscopy Center of the Federal University of Rio Grande do Sul for the microscopy analyzes and Miss. Karina Marckmann for technical assistance of SEM.

\section{References}

AKÉ-CASTILLO, JA., HERNÁNDEZ-BECERRIL, DU. and MEAVE del CASTILLO, ME., 1999. Species of the genus Thalassiosira (Bacillariophyceae) from the Gulf of Tehuantepec, Mexico. Botanica Marina, vol. 42, no. 4, p. 487-503.

FRANCO, CRP., 1991. Plankton diatoms of the Piaui River estuary (Brazil): seasonal distribution and biogeographic affinities. Kingston: Rhode Island University. [Dissertação de Mestrado]. Available from: <http://www.anp.gov.br/ ibamaperfuracao/refere/Regi\%E3o\%20Nordeste_PB_\%20 PE_\%20AL_\%20SE_\%20BA_ANEXO.pdf $>$. Access in: May 2006.

FRYXELL, GA., 1975. Three new species of Thalassiosira, with observations on the occluded process, a newly observed structure of diatom valves. Nova Hedwigia Beiheft, vol. 53, p. $57-73$.

FRYXELL, GA. and HASLE, GR., 1977. The genus Thalassiosira, some species with a modified ring of central strutted processes. Nova Hedwigia Beihef, vol. 54, p. 67-98.

HALLEGRAEFF, GM., 1984. Species of the diatom genus Thalassiosira in Australian waters. Botanica Marina, vol. 27, no. 11, p. 495-513.
HARRIS, ASD., MEDLIN, LK., LEWIS, J. and JONES, K., 1995. Thalassiosira species (Bacillariophyceae) from a Scotish sea-loch. European Journal of Phycology, vol. 30, no. 2, p. $117-131$.

HASLE, GR., 1968. The valve processes of the centric diatom genus Thalassiosira. Nytt Magasin for Botanik, vol. 15, p. 193-201

1972. Thalassiosira subtilis (Bacillariophyceae) and two allied species. Norwegian Journal of Botany, vol. 19, no. 3, p. 111-137.

1976. Examination of diatom type material: Nitzschia delicatissima Cleve, Thalassiosira minuscula Krasske, and Cyclotella nana Hustedt. British Phycological Journal, vol. 11, no. 2 , p. 101-110.

1983. The marine, planktonic diatoms Thalassiosira oceanica sp. nov. and T. partheneia. Journal of Phycology, vol. 19 , no. 2 , p. $220-229$

HASLE, GR. and FRYXELL, GA., 1977. The genus Thalassiosira: some species with a linear areola array. Nova Hedwigia Beiheft, vol. 54, p. 15-66.

HASLE, G. and SYVERTSEN, EE., 1996. Marine diatoms. In TOMAS, CR. (Ed.). Identifying marine diatoms and dinoflagellates. San Diego: Academic Press. 598 p.

HELMCKE, JG. and KRIEGER W., 1953. Diatomeenschalen im elektronenmikroskopischen Bild. Weinheim: J. Cramer. (vol. 1).

1954. Diatomeenschalen im elektronenmikroskopischen Bild. Weinheim: J. Cramer. (vol. 2).

HERNÁNDEZ-BECERRIL, DU. and TAPIA-PEÑA, MI., 1995. Planktonic diatoms from the Gulf of California and coasts off Baja California: species of the genus Thalassiosira. Botanica Marina, vol. 38, no. 4, p. 543-555.

HERZIG, WN. and FRYXELL, GA., 1986. The diatom genus Thalassiosira Cleve in Gulf Stream Warm Core Rings: Taxonomy, with $T$. intrannula and $T$. lineoides, spp. nov. Botanica Marina, vol. 29, no. 1, p. 11-25.

JOHANSEN, JR. and FRYXELL, GA., 1985. The genus Thalassiosira (Bacillariophyceae): studies on species occurring south of the Antarctic convergence zone. Phycologia, vol. 24, no. 2, p. 155-179.

KACZMARSKA, I., BEATON, M., BENOIT, AC. and MEDLIN, LK., 2005. Molecular phylogeny of selected members of the order Thalassiosirales (Bacillariophyta) and evolution of the fultoportula. Journal of Phycology, vol. 42, no. 1, p. 121-138.

LANGE, CB. and MOSTAJO, EL., 1985. Phytoplankton (diatoms and silicoflagellates) from the Southwestern Atlantic Ocean. Botanica Marina, vol. 28, no. 4, p. 469-476.

MAHOOD, AD., FRYXELL, GA. and McMILLAN, M., 1986. The diatom genus Thalassiosira: species form the San Francisco Bay system. Proceedings of the California Academy of Science, vol. 44, no. 8, p. 127-156.

MUYLAERT, K. and SABBE, K., 1996. The diatom genus Thalassiosira (Bacillariophyta) in the estuaries of the Schelde (Belgium/The Netherlands) and the Elbe (Germany). Botanica Marina, vol. 39, no. 2, p. 103-115. 
PROCOPIAK, LK., FERNANDES, LF. and MOREIRAFILHO, H., 2006. Diatomáceas (Bacillariophyta) marinhas e estuarina do Paraná, sul do Brasil: lista de espécies com ênfase em espécies nocivas. Biota Neotropica, vol. 6, no. 3. Available from: http://www.biotaneotropica.org.br/v6n3/pt/abstract?inve ntory+bn02306032006. Access in: Dec. 2006.

RIBEIRO, SMMS., 1996. Caracterização taxonômica e ecológica das comunidnades pico-nano e microplanctônicas, superficial e profunda, da zona eufótica do Atlântico Sul. São Paulo: Universidade de São Paulo. 155 p. [Tese de Doutorado].

RIVERA, PR., 1981. Beiträge zur Taxonomie und Verbreitung der Gatung Thalassiosira Cleve. Bibliotheca Phycologica, vol. $56,364 \mathrm{p}$.

SAR, EA., SUNESEN, I. and CASTAÑOS, C., 2001. Marine diatoms from Buenos Aires coastal waters (República
Argentina). I Thalassiosiraceae. Nova Hedwigia, vol. 73, no. 1-2, p. 199-228.

SAR, EA., SUNESEN, I. and LAVIGNE, AS., 2002. The diatom genus Thalassiosira: species form the northern San Matías Gulf (Río Negro, Argentina). Nova Hedwigia, vol. 74, no. 3-4, p. 373-386.

SIMONSEN, R., 1974. The diatom plankton of the Indian Ocean Expedition of R/V "Meteor". "Meteor" Forsch Ergebnisse, vol. 19 , no. D, p. 1-107.

TORGAN, L.C. and SANTOS, C.B. 2006. Thalassiosira weissflogii (Coscinodiscophyceae - Bacillariophyta) em ambientes lacustres na Planície Costeira do sul do Brasil. Iheringia. 61(1-2):135-138.

2007. Ocorrência de Thalassiosira nodulolineata (Bacillariophyta) na Laguna dos Patos, Brasil. R. bras. Bioci. 5(supl.2):714-716 